SAKAI SAMBAYAN — Jurnal Pengabdian kepada Masyarakat

\title{
PENGEMBANGAN WEBSITE DESA PEKON KILUAN NEGERI MENUJU KAWASAN WISATA BERBASIS TIK
}

\author{
Helmy Fitriawan, Umi Murdika, Afri Yudamson \\ Jurusan Teknik Elektro Fakultas Teknik Universitas Lampung \\ Jl. Prof. Sumantri Brojonegoro No.1 Bandar Lampung 35145 \\ Penulis Korespodensi : helmy.fitriawan@eng.unila.ac.id \\ umi.murdika@eng.unila.ac.id \\ afri.yudamson@eng.unila.ac.id
}

\begin{abstract}
Abstrak
Pekon Kiluan Negeri merupakan salah satu target wisata di daerah Lampung yang banyak menarik minat wisatawan. Letaknya yang jauh dari pusat kota dan akses jalan yang kurang memadai menjadi faktor penghambat penyebaran informasi dan promosi. Di lain pihak, perkembangan teknologi informasi dan komunikasi (TIK) semakin pesat. Pengguna internet di Indonesia sebesar 132,7 juta jiwa dari total populasi penduduk Indonesia 256,2 juta jiwa yang menunjukkan tingginya minat masyarakat Indonesia dalam mengakses informasi melalui internet. Hal ini menjadi peluang untuk mempromosikan potensi desa dan wisata Pekon Kiluan Negeri melalui internet. Dengan demikian, perlu dilakukan kegiatan pengabdian kepada masyarakat berupa pemberian pelatihan dan bimbingan kepada masyarakat Pekon Kiluan Negeri dalam memanfaatkan teknologi informasi dan komunikasi (TIK) untuk pengembangan website desa. Website desa yang dikembangkan berisi informasi sistem pemerintahan, latar belakang, dan lokasi dari berbagai pilihan wisata. Kegiatan ini dapat mempermudah sarana promosi desa dan juga dapat meningkatkan kompetensi sumber daya manusia dalam hal pemanfaatan TIK.
\end{abstract}

Kata kunci: target wisata, TIK, website desa, promosi desa wisata

\section{Pendahuluan}

Provinsi Lampung banyak menyimpan keindahan alam yang menarik sebagai tempat wisata. Salah satunya di Pekon Kiluan Negeri kabupaten Tanggamus. Secara geografis Pekon Kiluan Negeri berbatasan langsung dengan Samudera Hindia sehingga memiliki potensi wisata laut yang menarik untuk dikunjungi.

Letak geografis yang jauh dari ibu kota provinsi dan akses jalan yang kurang memadai menjadi faktor penghambat penyebaran informasi dan promosi. Wisatawan yang datang masih dalam jumlah terbatas. Hal ini dikarenakan kurangnya informasi tentang sarana dan prasarana di Pekon Kiluan.

Sementara itu di sisi lain, perkembangan teknologi informasi dan komunikasi (TIK) semakin pesat. TIK dimanfaatkan di berbagai bidang, tidak hanya dalam penyebaran informasi namun juga sebagai media promosi, transaksi jual beli, sistem informasi, dan lain sebagainya.
Berdasarkan data statistik pengguna internet di Indonesia diketahui bahwa pengguna internet di Indonesia adalah 132,7 Juta jiwa dari total populasi penduduk Indonesia 256,2 Juta jiwa. Hal ini menunjukkan tingginya minat masyarakat Indonesia dalam mengakses informasi melalui internet, baik dari media sosial maupun website. Kondisi ini merupakan peluang untuk mempromosikan potensi desa dan wisata Pekon Kiluan Negeri melalui internet.

Dari analisis situasi tersebut maka diperlukan suatu upaya untuk menjembatani potensi desa dan wisata dengan pemanfaatan teknologi informasi dan komunikasi. Adapun langkah yang dapat diambil yaitu memberikan pelatihan dan pendampingan pengembangan website desa di Pekon Kiluan Negeri. Website desa tidak hanya sebagai media keterbukaan informasi pemerintahan desa, tetapi juga dimanfaatkan sebagai media promosi potensi desa dan wisata.

Kegiatan pengabdian kepada masyarakat ini bertujuan untuk memberikan pelatihan dan bimbingan kepada masyarakat Pekon Kiluan 
Negeri, dalam memanfaatkan teknologi informasi dan komunikasi. Kegiatan dilaksanakan dengan memberikan pelatihan dan pendampingan pengelolaan website sebagai media promosi Pekon Kiluan Negeri. Dari kegiatan ini diharapkan dapat bermanfaat untuk meningkatkan kompetensi sumber daya manusia di Pekon Kiluan Negeri dalam rangka pemanfaatan TIK untuk promosi kawasan wisata.

\section{Metode}

\section{A. Kerangka Pemecahan Masalah}

Dari kondisi yang dikemukakan dalam analisis situasi maka pemecahan masalah yang telah dirumuskan di atas dilakukan dalam bentuk pengembangan website desa Pekon Kiluan Negeri. Peserta diberi pelatihan dan pendampingan pengembangan website desa untuk promosi potensi desa dan wisata.

\section{B. Khalayak Sasaran}

Khalayak sasaran dari kegiatan ini adalah pengelola website desa dan Pokdarwis pekon Kiluan Negeri.

\section{Metode yang Digunakan}

Metode yang digunakan dalam kegiatan pendampingan ini adalah penyampaian penjelasan mengenai konsep teknologi informasi dan telekomunikasi dan pendampingan selama waktu pengabdian untuk optimalisasi fungsi TIK dalam mendukung promosi wisata. Materi kegiatan yang diberikan adalah pemanfaatan website desa sebagai media promosi potensi wisata. Kemudian tim pengabdian bersama-sama dengan perangkat desa mengumpulkan data dan informasi terkait potensi wisata. Tim pengabdian memberikan pelatihan pengembangan website desa. Tim pengabdian melakukan pendampingan kepada pengelola website desa dan perangkat desa sampai dapat mengelola website secara mandiri.

\section{Hasil dan Pembahasan}

Website Desa Kiluan Negeri dibangun dengan domain desa.id yang bersumber dari pemerintah untuk memfasilitasi desa-desa untuk dapat mempromosikan komoditas maupun potensi wisata setempat. Domain tersebut disediakan untuk seluruh desa yang ingin membuat website. Desain website menggunakan tema yang sudah disediakan di domain website tersebut. Dengan demikian, pengelola tidak perlu menggunakan bahasa pemrograman untuk dapat mengelola website. Pengelola hanya perlu menyiapkan data berupa foto-foto beserta narasinya untuk dapat ditampilkan di website. Data tersbut dikumpukan bersama dengan tim pengabdian dengan lebih dulu membuat daftar kebutuhan data website seperti foto-foto lokasi wisata, aspek konsumtif bagi wisatawan, dan data narasinya.

Website desa yang dikembangkan berisi informasi sistem pemerintahan, latar belakang, dan lokasi dari berbagai pilihan wisata. Berikut beberapa tampilan website sebagai hasil dari kegiatan ini.

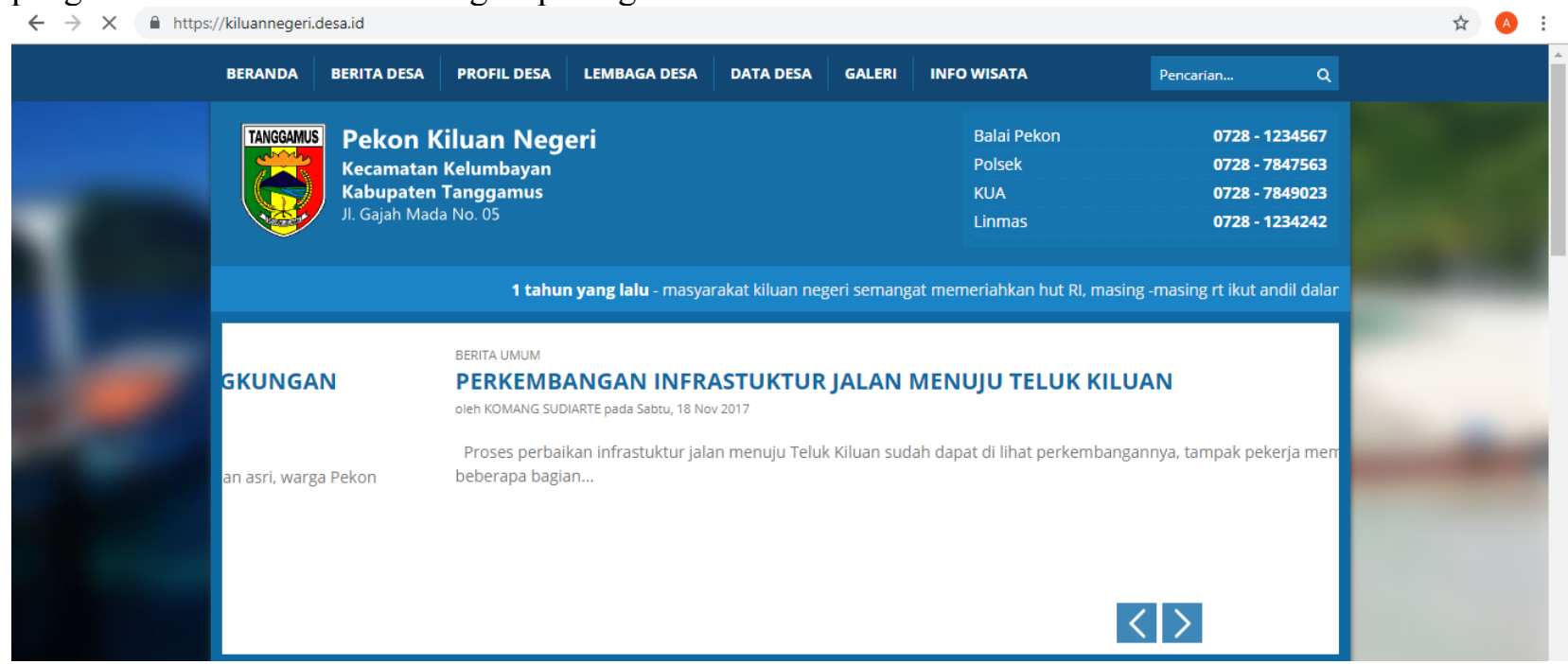

Gambar 1. Homepage website Desa Kiluan Negeri 


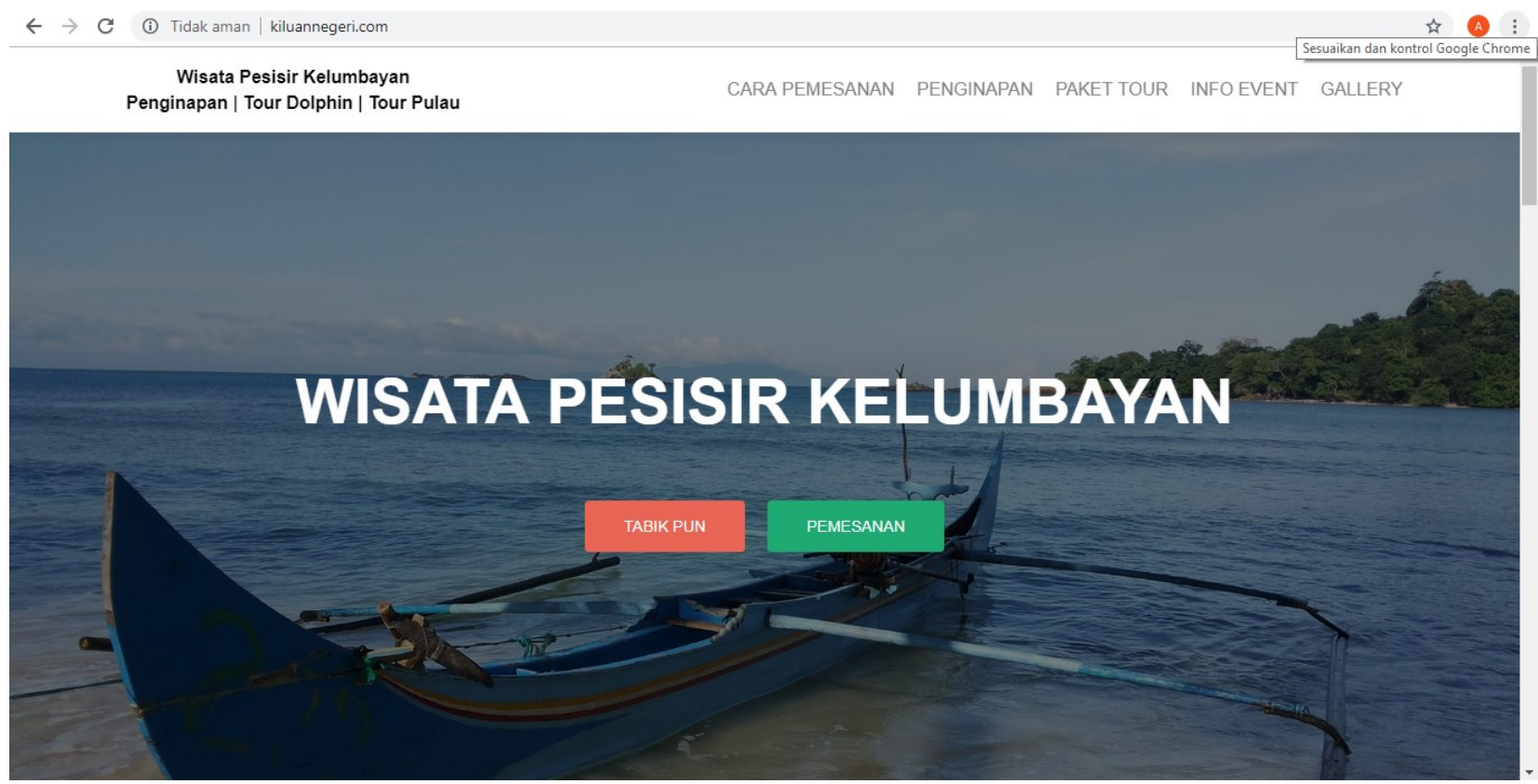

Gambar 2. Halaman wisata Desa Kiluan Negeri

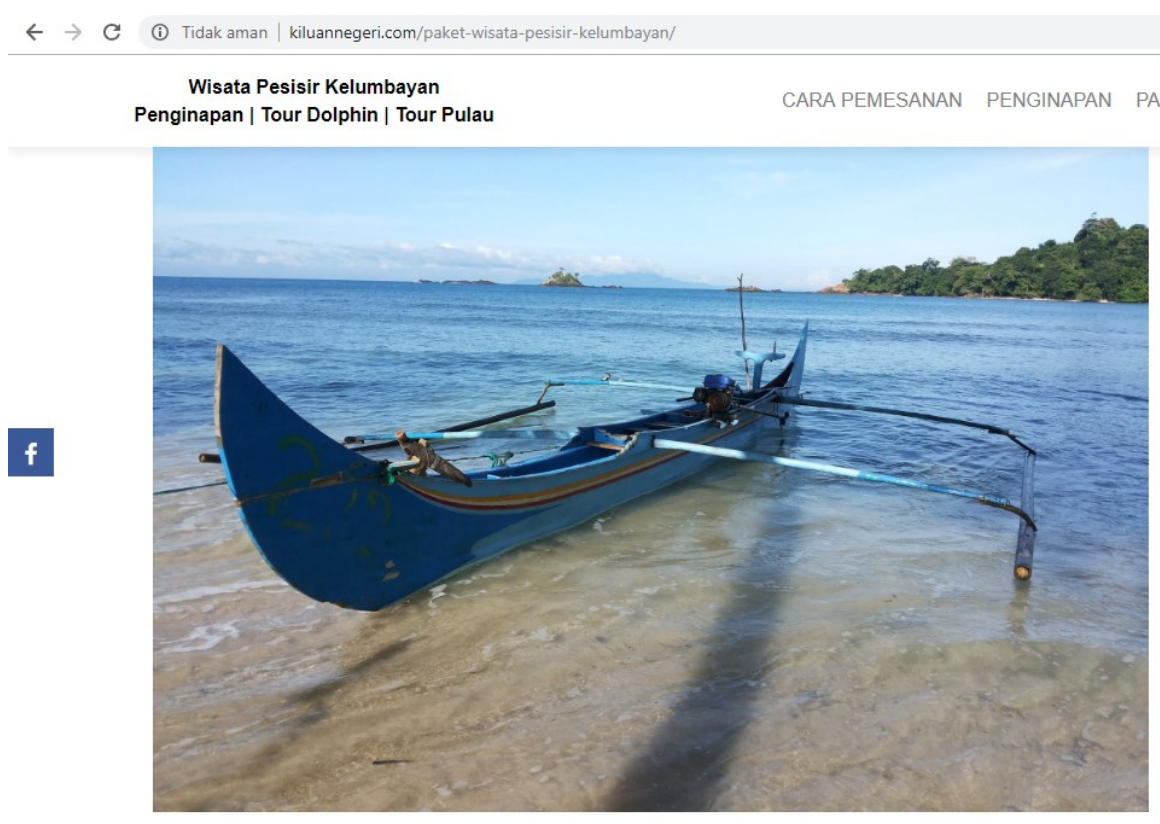

Gambar 3. Halaman pilihan wisata Desa Kiluan Negeri

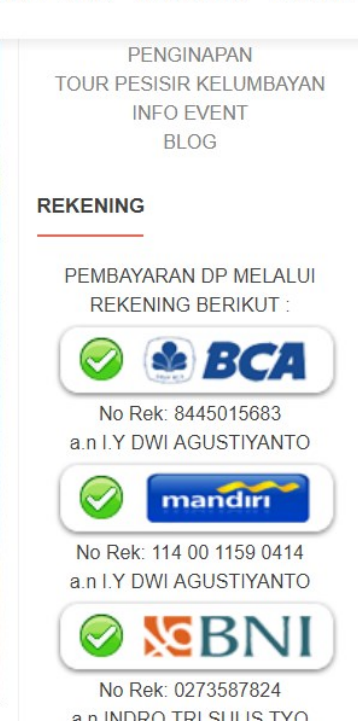

Gambar 1 menunjukkan halaman utama website Desa Kiluan Negeri. Pada halaman tersebut tertera menu Info Wisata untuk menuju halaman yang beirisi tentang berbagai pilihan wisata di Desa Kiluan Negeri.

Gambar 2 menunjukkan halaman wisata Desa Kiluan Negeri. Pada halaman tersebut tertera link untuk reservasi, pilihan penginapan, paket tour, info event, dan dokumentasi berupa foto-foto yang menampilkan keindahan Desa Wisata Kiluan Negeri.
Gambar 3 menunjukkan halaman pilihan wisata di Desa Kiluan Negeri. Pada halaman ini dijelaskan tawaran wisata di beberapa lokasi unggulan. Penjelasan berupa momen apa saja yang bisa dinikmati wisatawan seperti debur ombak, pasir pantai, angin laut, perjalanan di atas perahu, wisata alam batu karang yang menyerupai gigi hiu, dan juga wisata untuk bertemu langsung dengan lumba-lumba. Beberapa paket wisata dapat dinikmati di lokasi yang berbeda. Dengan 
demikian, wisatawan dapat menyusun rencana wisata sesuai dengan target yang diinginkan.

Keseluruhan halaman website dikerjakan oleh pemuda setempat yang telah ditunjuk oleh kepala Desa dan dengan diarahkan dan didampingi oleh tim pengabdian kepada masyarakat Fakultas Teknik Universitas Lampung. Dengan adanya kegiatan ini, TIK setempat dapat dimanfaatkan secara optimal melalui pengelolaan website desa.

\section{Kesimpulan}

Kesimpulan yang didapat kan dari kegiatan ini adalah kegiatan pengabdian kepada masyarakat ini telah memberikan pelatihan dan bimbingan kepada masyarakat Pekon Kiluan Negeri dalam memanfaatkan TIK untuk pengelolaan website sebagai media promosi sehingga meningkatkan kompetensi sumber daya manusia di Pekon Kiluan
Negeri dalam rangka pemanfaatan TIK untuk promosi kawasan wisata.

\section{Ucapan Terima Kasih}

Terima kasih disampaikan kepada LPPM UNILA yang telah mendanai pengabdian ini melalui hibah DIPA FT Unila Tahun Anggaran 2018.

\section{Daftar Pustaka}

http://isparmo.web.id/2016/11/21/data-statistikpengguna-internet-indonesia-2016. Diakses tanggal 01 Agustus 2017

Muhammad Badri. Pembangunan Pedesaan Berbasis Teknologi Informasi Dan Komunikasi (Studi pada Gerakan Desa Membangun) . Jurnal RISALAH, Vol. 27, No. 2, Desember 2016: 6273. 